\title{
IMPLIKASI PENERAPAN ACTIVITY BASED COSTING SYSTEM TERHADAP KINERJA PERUSAHAAN DAN KEUNGGULAN BERSAING
}

\author{
Diah Anugrah Sharasanti \\ Program Studi Akuntansi Politeknik Ubaya \\ Jalan Ngagel Jaya Selatan No.169 Surabaya \\ diahanugrah@staff.ubaya.ac.id
}

\begin{abstract}
The strategy for determining the accurate production cost is one way for the company to compete among its competitors. Activity Based Costing assumes all costs have a cause, and the causes can be managed so that the costs charged can be effective and efficient. Several studies have shown that there are differences in production costs between calculations using traditional methods and Activity Based Costing. Previous studies have shown that production costs are more accurate when using the Activity Based Costing method of calculation. Bjornenak and Mitchell (1999) in Rendy and Devie (2013) argue that Activity Based Costing is a system that is promoted and adopted as a basis for strategic decision-making and to improve earnings performance. According to Reimann (1990) the use of the Activity Based Costing system encourages companies to produce products that have competitive advantages. The results of several studies show that the ability of the Activity Based Costing system can not only measure product costs accurately, but the information generated can be used for various other strategic interests within the company, and the implementation of the Activity Based Costing system is not only focused on the financial aspects, but also on other nonfinancial aspects which are indicators of the success of company performance.
\end{abstract}

Keywords: Activity Based Costing system, competitive advantages, company performance.

\begin{abstract}
ABSTRAK
Strategi penentuan biaya produksi yang tepat merupakan salah satu cara agar perusahaan dapat bersaing di antara para kompetitornya. Activity Based Costing menganggap semua biaya ada penyebabnya, dan penyebabnya tersebut bisa dikelola agar biaya yang dibebankan bisa efektif dan efisien. Beberapa penelitian telah menunjukkan bahwa terjadi perbedaan terhadap biaya produksi antara perhitungan dengan metode tradisional dan Activity Based Costing. Penelitianpenelitian terdahulu menunjukkan bahwa biaya produksi lebih akurat ketika menggunakan metode perhitungan Activity Based Costing. Bjornenak and Mitchell (1999) dalam Rendy dan Devie (2013) berpendapat bahwa Activity
\end{abstract}


Based Costing adalah sistem yang dipromosikan dan diadopsi sebagai dasar pembuat keputusan strategis dan untuk meningkatkan kinerja laba. Menurut Reimann (1990) penggunaan Activity Based Costing system mendorong perusahaan untuk menghasilkan produk yang mempunyai keunggulan bersaing. Dari hasil telaah beberapa penelitian menunjukkan bahwa kemampuan Activity Based Costing system tidak hanya dapat mengukur biaya produk secara tepat, namun dari informasi yang dihasilkan dapat digunakan untuk berbagai kepentingan strategis lain dalam perusahaan dan implementasi Activity Based Costing system tidak hanya terfokus pada aspek finansial, namun juga pada aspek non finansial lain yang merupakan indikator keberhasilan kinerja perusahaan.

Kata kunci: Activity Based Costing system, keunggulan bersaing, kinerja perusahaan.

\section{PENDAHULUAN}

Perkembangan yang sangat cepat pada teknologi informasi dan komunikasi pada beberapa tahun terakhir telah membawa dunia mencapai tahap Revolusi Industri 4.0. Revolusi Industri 4.0 merupakan tahap ke-4 dari revolusi industri sebelumnya. Pada masing-masing tahap, terjadi perubahan-perubahan yang semakin lama semakin maju dan memudahkan manusia untuk melakukan pekerjaan sehari-hari. Menurut Suharman (2019) era Revolusi Industri 4.0 adalah era industri transisi. Era ini memberikan dampak yang sangat besar dan luas terutama pada sektor lapangan kerja di dunia (Satya, 2018). Peralihan teknologi ke arah digitalisasi membawa dampak bagi sektor industri, baik sektor manufaktur maupun jasa. Perubahan yang super cepat menyebabkan hampir semua sektor industri dan jasa terkena imbas, dari mulai faktor-faktor produksi hingga ke distribusi dan pemasaran (Rahman dan Wartoyo, 2018). Dalam konteks faktor produksi, digitalisasi memungkinkan terjadinya interkoneksi antara mesin fisik dengan sistem produksi, sehingga efektivitas dan efisiensi biaya akan meningkat. Peningkatan efektivitas dan efisiensi dalam sistem produksi akan mengurangi biaya produksi. Namun, tidak semua industri dapat menyikapi perubahanperubahan ini dengan cepat. Menurut Rahman dan Wartoyo (2018) masih banyak industri yang masih menggunakan teori produksi klasik, sehingga mengalami kesulitan bersaing dengan industri-industri yang telah menerapkan konsep mutakhir dalam bidang produksi.

Strategi penentuan biaya produksi yang tepat merupakan salah satu cara agar perusahaan dapat bersaing diantara para kompetitornya. Menurut Rahmaji (2013) ketidaktepatan dalam perhitungan biaya produksi membawa dampak yang merugikan bagi perusahaan, karena penetapapan biaya produksi berfungsi sebagai dasar untuk menetapkan harga jual dan laba, sebagai alat untuk mengukur efisiensi pelaksanaan proses produksi, serta sebagai dasar pengambilan keputusan bagi manajemen. Kesalahan di dalam menetapkan harga jual mengakibatkan perusahaan tidak dapat mencapai keunggulan bersaing di era Revolusi Industri 4.0 yang sangat kompetitif. Menurut Dicky dan Martusa (2011) dalam Marlina et al. 
(2018) cara-cara untuk mencapai keunggulan bersaing adalah dengan mengurangi biaya, meningkatkan produktivitas, meningkatkan kualitas pelayanan, dan meningkatkan kemampuan untuk memberi respon terhadap kebutuhan stakeholder. Sedangkan menurut Marlina et al. (2018) keunggulan bersaing ini dapat diciptakan dengan cara memberikan kualitas yang baik, harga yang lebih murah, dan pelayanan kepada pelanggan yang memuaskan.

Penentuan harga jual yang murah dan dapat bersaing menuntut perusahaan harus dapat menghitung biaya produksi secara akurat. Menurut Sumarsid (2011) salah satu penyebab tidak akuratnya perhitungan biaya produksi adalah karena perhitungan biaya tidak langsung (biaya overhead) yang tidak akurat. Salah satu metode perhitungan biaya produksi yang dianggap paling akurat adalah dengan menggunakan pendekatan Activity Based Costing System. Yudiastra (2017) mengatakan bahwa metode ini berpedoman pada proses penentuan biaya produk, yaitu dengan cara menentukan aktivitas-aktivitas yang diserap produk tersebut selama proses produksi, sehingga dapat membantu manajemen dalam pengambilan keputusan serta mengalokasikan biaya secara akurat. Menurut Rahmaji (2013) Activity Based Costing System merupakan metode akuntansi biaya di mana pembebanan harga pokok produk merupakan penjumlahan seluruh biaya aktvitas yang menghasilkan (produk) barang atau jasa. Dasar alokasi yang digunakan adalah jumlah aktivitas dalam setiap cost pool tersebut. Metode ini menggunakan jenis pemicu biaya yang lebih banyak, sehingga dapat mengukur sumber daya yang digunakan oleh produk secara lebih akurat. Hilton et al. (2003) berpendapat bahwa Activity Based Costing merupakan sistem perhitungan biaya yang berusaha memperbaiki sistem perhitungan tradisional dengan menekankan pada aktivitas sebagai dasar penetapan biaya. Activity Based Costing menganggap semua biaya ada penyebabnya dan penyebabnya tersebut bisa dikelola agar biaya yang dibebankan bisa efektif dan efisien. Beberapa penelitian telah menunjukkan bahwa terjadi perbedaan terhadap biaya produksi antara perhitungan dengan metode tradisional dan Activity Based Costing system. Penelitian-penelitian tersebut menunjukkan bahwa biaya produksi lebih akurat ketika menggunakan metode perhitungan Activity Based Costing system. Akyol et al. (2005) menunjukkan bahwa Activity Based Costing system dapat memperlihatkan apakah biaya suatu produk undercosting (terlalu rendah pembebanan biayanya) ataukah overcosting (terlalu tinggi dalam pembebanan biayanya). Pawiyataningrum et al. (2014) dalam analisisnya terhadap perusahaan manufaktur PT Indonesia Pet Bottle Pandaan, Pasuruan, menemukan bahwa ketika menggunakan Activity Based Costing system terdapat produk yang mengalami overcosting dan undercosting. Hasil penelitian Turney (1989) dan Rof and Andreica (2011) dalam Noviyarsi et al. (2017) menemukan bahwa metode Activity Based Costing system memberikan suatu informasi untuk dijadikan pengambilan keputusan strategis, pemilihan desain produk yang tepat, mengevaluasi dan menyederhanakan sistem dengan melakukan perbaikan aktivitas sehingga mampu menghasilkan produk dengan biaya produksi yang tepat. Bjornenak and Mitchell (1999) dalam Rendy dan Devie (2013) juga berpendapat bahwa Activity Based Costing adalah sistem yang dipromosikan dan diadopsi sebagai dasar pembuat keputusan strategis dan untuk meningkatkan kinerja laba. Menurut Reimann (1990) penggunaan Activity Based 
Costing system mendorong perusahaan untuk menghasilkan produk yang mempunyai keunggulan bersaing.

Dari paparan diatas, akan dikaji lebih lanjut apakah penggunaan metode Activity Based Costing system akan meningkatkan kinerja laba dan sekaligus dapat menghasilkan produk yang mempunyai keunggulan bersaing, dengan membandingkan beberapa hasil penelitian dan membahas secara teori tentang manfaat, keunggulan, serta kelemahannya.

\section{TINJAUAN PUSTAKA}

\section{Pengertian Activity Based Costing}

Activity Based Costing merupakan sistem akuntansi biaya yang dikembangkan oleh Cooper dan Kaplan pada akhir 1980 (Rendy dan Devie, 2013). Menurut Blocher et al. (2005) Activity Based Costing adalah pendekatan perhitungan biaya yang membebankan biaya sumber daya ke objek biaya seperti produk atau jasa berdasarkan aktivitas yang dilakukan untuk objek biaya tersebut. Carmelita et al. (2017) menyebutkan bahwa Activity Based Costing adalah suatu metode sistem perhitungan biaya produksi yang dibebankan berdasarkan aktivitasaktivitas penyebab terjadinya biaya. Pada dasarnya Activity Based Costing system adalah metode akuntansi biaya untuk melakukan pembebanan harga pokok produk dengan menjumlahkan seluruh biaya aktivitas yang menghasilkan barang atau jasa (Witjaksono, 2013).

Terdapat tiga komponen dasar dalam Activity Based Costing system, menurut Rayborn and Kinney (2013) dalam Indrasurya et al. (2016) yaitu:

1. Mengenali pembebanan biaya yang terjadi dalam seluruh tingkat level organisasi yang berbeda.

2. Mengakumulasi biaya terkait ke dalam individual cost pools.

3. Menggunakan berbagai cost drivers untuk menentukan biaya produksi atau jasa.

Mulyadi (2003) menyebutkan bahwa Activity Based Costing merupakan suatu sistem perhitungan biaya di mana tempat biaya overhead pabrik yang jumlahnya lebih dari satu dialokasikan menggunakan dasar yang memasukkan satu atau lebih faktor yang tidak berkaitan dengan volume (non-volume related factor). Tsai (1998) berpendapat bahwa Activity Based Costing merupakan sistem penentuan biaya dua tahap untuk memperoleh pembiayaan yang akurat. Pertama, berbagai objek biaya yang ada seperti dari departemen, produk, pelanggan, dan saluran (channel) ditelusuri biaya per aktivitas. Kedua, setelah menelusuri sumber biaya dari aktivitas selanjutnya ditelusuri biaya per aktivitas pada objek biayanya masing-masing.

Menurut Hakim (2018) secara sederhana Activity Based Costing memiliki tingkat presisi yang jauh lebih baik dibandingkan dengan teknik perhitungan biaya tradisional. Hal ini disebabkan sistem biaya tradisional mengalokasikan biaya overhead pabrik melalui jam kerja yang ada sehingga biaya akhir yang dibebankan kurang tepat. Activity Based Costing system melihat kekurangan ini sehingga pembebanan biaya dilakukan dalam dua tahap yang berbeda dan menggunakan driver level unit, level batch, dan level produk agar memperoleh akurasi yang lebih baik guna pembuatan keputusan manajerial. 
Dari beberapa pendapat di atas, dapat dikatakan bahwa Activity Based Costing system melakukan pembebanan biaya sumber daya ke dalam objek biaya (produk, jasa, dan konsumen) berdasarkan aktivitas yang dilakukan untuk objek biaya, atau dengan kata lain produk atau jasa yang dihasilkan adalah hasil dari aktivitas, dan aktivitas tersebut merupakan penggunaan sumber daya yang menghasilkan biaya. Menurut Siregar et al. (2013) terdapat dua keyakinan dasar dalam Activity Based Costing system, yaitu:

1. Biaya merupakan akibat dari pelaksanaan aktivitas dan aktivitas merupakan penyebab munculnya biaya. Oleh karena itu, perlu pemahaman yang mendalam mengenai aktivitas dan hal yang menyebabkan aktivitas tersebut perlu dilakukan.

2. Penyebab biaya, yaitu aktivitas, dapat dikelola. Pengelolaan ini dapat menjadi penyebab timbulnya biaya, personil perusahaan dapat mempengaruhi besar kecilnya biaya. Untuk dapat melakukan pengelolaan yang baik, perlu informasi yang andal mengenai biaya dan penyebabnya (aktivitas).

\section{Hirarki Activity Based Costing}

Dalam Activity Based Costing system, biaya sumber daya diidentifikasi pada berbagai aktivitas. Perusahaan harus mengelompokkan seluruh aktivitas berdasarkan seberapa besar aktivitas-aktivitas tersebut mengonsumsi sumber daya. Aktivitas-aktivitas ini dibagi kedalam empat tingkat, yang disebut juga sebagai hirarki Activity Based Costing system (Blocher et al., 2007), yaitu:

1. Aktivitas Tingkat Unit (unit level activity), dilakukan pada setiap satu unit produk atau jasa perusahaan. Contoh aktivitas tingkat unit adalah pemakaian bahan baku langsung, pemakaian jam tenaga kerja langsung, serta pemasukan komponen dan inspeksi setiap unit. Aktivitas tingkat unit adalah berdasarkan volume. Aktivitas yang dibutuhkan bervariasi secara proporsional dengan jumlah objek biaya. Penggerak konsumsi sumber daya dan penggerak konsumsi aktivitas cenderung sama untuk aktivitas tingkat unit.

2. Aktivitas Tingkat Batch (batch level activity), dilakukan untuk masingmasing setiap batch, baik batch untuk produk ataupun jasa. Perusahaan melakukan aktivitas pada tingkat batch untuk setiap batch produk atau jasa yang dijadwalkan untuk proses bersama, bukan untuk setiap unit individu dari objek biaya. Satu batch memiliki lebih dari satu unit produk atau jasa atau lebih dari itu. Contoh aktivitas tingkat batch adalah persiapan, penyetelan, atau persiapan mesin, pemesanan pembelian, penjadwalan produksi, inspeksi per batch, penanganan bahan baku, dan percepatan proses produksi.

3. Aktivitas Pendukung Produk (product sustaining activity) dimaksudkan untuk mendukung produksi produk atau jasa tertentu. Contoh aktivitas pendukung produk adalah desain produk, administrasi suku cadang bagi produk, dan keterlibatan dalam perubahan rekayasa untuk memodifikasi produk.

4. Aktivitas Pendukung Fasilitas (facility sustaining activity) mendukung operasi secara umum. Aktivitas ini tidak disebabkan oleh produk atau 
kebutuhan pelayanan pelanggan dan tidak dapat ditelusuri ke satu unit, batch, atau produk. Contoh aktivitas ini adalah penyediaan keamanan dan keselamatan kerja, pemeliharaan mesin dengan fungsi umum, pengelolaan pabrik, pembayaran pajak bangunan, dan asuransi pabrik, serta penutupbukuan tiap bulan.

\section{Tahapan Implementasi Activity Based Costing System}

Menurut Miller (1992) dalam Gunasekaran et al. (1999) terdapat beberapa tahap di dalam mengimplementasikan Activity Based Costing system, yaitu:

1. Klasifikasi Biaya, terdapat dua jenis utama metode alokasi biaya overhead. Pertama, biaya departemen pendukung dialokasikan dengan menggunakan satu atau lebih dasar alokasi, metode kedua, beban pada pusat biaya diakumulasikan dan kemudian dialokasikan dengan menggunakan basis seperti jam tenaga kerja atau jam mesin. Alokasi biaya pada sistem berbasis unit ditetapkan proporsinya pada volume produksi. Biaya overhead ditetapkan secara linier pada perubahan hasil produksi, sedangkan alokasi biaya pada Activity Based Costing system tidak semua biaya dianggap berubah secara proporsional seiring perubahan hasil produksi. Terdapat dua basis alokasi yang mungkin: (1) basis level batch, di mana masukan tertentu dikonsumsi secara linier dan proporsional sejumlah batch pada setiap jenis yang diproduksi, (2) basis level produk, beberapa input tertentu dikonsumsi untuk mengembangkan dan memperkenankan produksi atas produk.

2. Langkah Keseluruhan pada Aktivitas. Tidak menutup kemungkinan aktivitas yang dibutuhkan dalam membuat produk sangat banyak. Dalam hal ini, tidak layak secara ekonomis jika menggunakan cost driver pada masing-masing aktivitas. Karena itu, terdapat trade-off antara keakuratan biaya dan pengukuran yang seharusnya dibangun selagi menggabungkan tugas yang terpisah ke dalam jumlah aktivitas yang terbatas. Ketika sejumlah tugas yang disatukan terlalu besar, maka keakuratan dari kemampuan penelusuran biaya akan berkurang.

3. Melaporkan Biaya Aktivitas. Langkah selanjutnya dalam merancang Activity Based Costing system adalah pelaporan biaya dari aktivitas keseluruhan. Trade-off akan terjadi dalam pelaporan biaya demi kemudahan. Terkadang informasi yang diberikan sangat rinci dan tidak perlu interpretasi. Selain itu, sangat mungkin untuk menggabungkan beberapa tindakan ke dalam aktivitas untuk sistem biaya, tapi melaporkannya terpisah. Dalam hal ini, hanya level pelaporan yang rinci yang terpengaruh tapi tidak dengan biaya produk yang dilaporkan.

4. Mengidentifikasi pusat aktivitas. Tahapan ini melibatkan identifikasi pusat aktivitas yang bertanggungjawab. Sebuah pusat aktivitas didefinisikan sebagai sebuah segmen proses produksi di mana manajemen menginginkan laporan biaya atas aktivitas tersebut secara terpisah, sehingga manajemen dapat mengendalikan aktivitas individual dalam perusahaan dengan efektif, terutama berkaitan dengan biaya.

5. Seleksi cost driver tahap pertama. Perbedaan utama antara penelusuran dua tahap dibandingkan dengan penggunaan satu tahap bahwa cost driver yang 
berbeda dapat digunakan pada masing-masing tahapan. Hal ini merupakan keuntungan utama bahwa terdapat divisi dari informasi yang tersedia baik pusat biaya dan level produk. Kadang kala lebih berguna jika kita memiliki informasi level pusat daripada level produk. Pada tahap pertama, biaya dari masukan (input) ditelusuri pada cost pool dalam masing-masing pusat aktivitas. Cost driver yang dipilih akan menentukan jumlah biaya dalam setiap pool. Ini akan meningkatkan akurasi biaya yang dilaporkan.

6. Seleksi cost driver tahap kedua. Ketika biaya dari semua aktivitas pada berbagai pusat biaya ditelusuri pada cost pool aktivitas. Kemudian cost driver tahap kedua dapat dipilih. Mengacu pada hal ini, biaya akan dialokasikan pada objek biaya. Ketika beralih pada Activity Based Costing system, pemilihan cost driver tahap kedua sangat dipengaruhi oleh peralihan itu. Perlu diingat bahwa tingkat kompleksitas pada proses pemanufakturan modern sangatlah besar. Karena itu, diperlukan pengembangan sistem biaya yang ekonomis untuk mempertahankan dan tidak memberikan distorsi yang berlebihan.

Menurut Dunia dan Abdullah (2012) dalam Rahmaji (2013) tahapan penyusunan hingga implementasi Activity Based Costing system adalah sebagai berikut:

1. Memeriksa ulang seluruh informasi keuangan perusahaan.

2. Menentukan tujuan penerapan Activity Based Costing system.

3. Menetapkan aktivitas utama yang menyebabkan perubahan pada beban tidak langsung (biaya overhead).

4. Menghubungkan biaya tidak langsung dengan aktivitas sehingga dapat dihitung tarif (rate) per unit untuk setiap dasar alokasi yang digunakan untuk membebankan biaya tidak langsung.

5. Menghitung biaya tidak langsung yang akan dibebankan pada setiap objek biaya.

6. Menghitung total biaya untuk setiap objek biaya.

7. Menggunakan hasil perhitungan Activity Based Costing tersebut untuk melakukan perbaikan dan pengambilan keputusan yang relevan.

Noviyarsi et al. (2017) menyebutkan bahwa prosedur perhitungan harga pokok produksi dengan Activity Based Costing system melalui dua tahap, yaitu:

1. Prosedur tahap pertama, terdiri dari:

a. Identifikasi aktivitas.

b. Biaya-biaya dibebankan ke aktivitas.

c. Aktivitas yang berkaitan dikelompokkan untuk membentuk kumpulan aktivitas.

d. Biaya aktivitas yang dikelompokkan dijumlahkan untuk mendefinisikan kelompok.

e. Tarif biaya overhead pabrik kelompok dihitung.

2. Prosedur tahap kedua, yaitu menghasilkan rumusan atau formula pembebanan overhead dari setiap kelompok biaya kepada setiap produk.

Prosedur Kalkulasi Biaya dengan Activity Based Costing system seperti terlihat pada bagan di Gambar 1. 


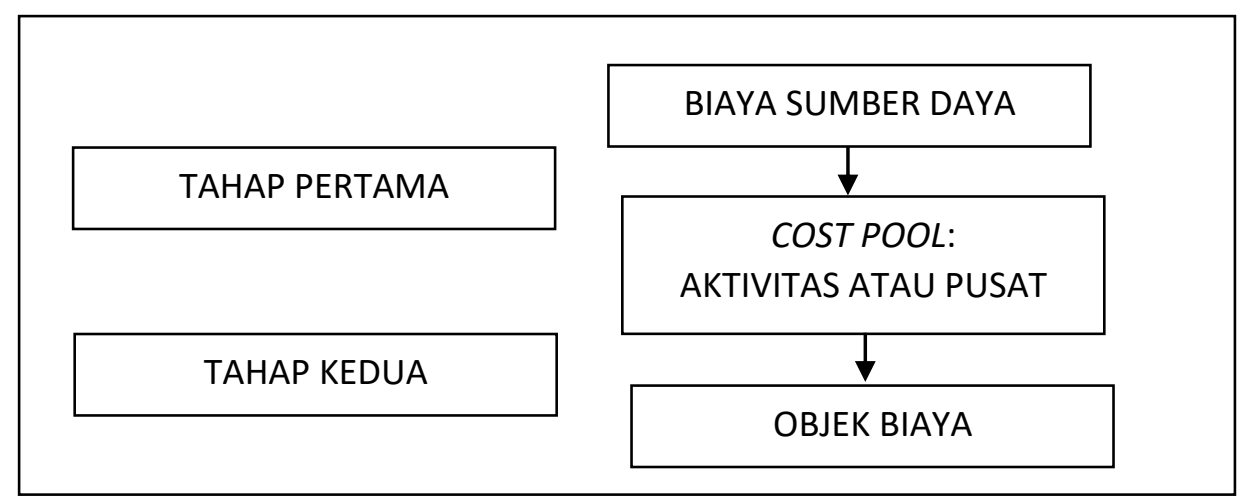

Gambar 1

Prosedur Kalkulasi Biaya Activity Based Costing system

\section{Perbandingan Antara Sistem Tradisional Dan Sistem Activity Based Costing}

Menurut Widjaya (1992) perbedaan antara metode tradisional dengan Activity Based Costing system adalah sebagai berikut:

1. Sistem biaya Activity Based Costing menggunakan aktivitas sebagai pemicu biaya (cost driver) untuk menentukan seberapa besar konsumsi overhead dari setiap produk, sedangkan sistem biaya tradisional mengalokasikan biaya overhead secara arbitrer berdasarkan satu atau dua basis alokasi yang non representative.

2. Sistem biaya Activity Based Costing memfokuskan pada biaya, mutu, dan faktor waktu. Sistem biaya tradisional terfokus pada performansi keuangan jangka pendek seperti laba. Apabila sistem biaya tradisional digunakan untuk penentuan harga dan profitabilitas produk, angka-angkanya tidak dapat diandalkan.

3. Sistem biaya Activity Based Costing memerlukan masukan dari seluruh departemen. Persyaratan ini mengarah ke integrasi organisasi yang lebih baik dan memberikan suatu pandangan fungsional silang mengenai organisasi

Menurut Adi (2005) perbedaan antara Activity Based Costing system dan sistem tradisional seperti terlihat pada Tabel 1 .

Tabel 1

Perbedaan antara $A B C$ system dan sistem Tradisional

\begin{tabular}{|l|l|l|}
\hline \multicolumn{1}{|c|}{ Keterangan } & \multicolumn{1}{|c|}{$\boldsymbol{A B C}$ system } & \multicolumn{1}{c|}{ Sistem Tradisonal } \\
\hline Dasar alokasi & Aktivitas & $\begin{array}{l}\text { Unit produksi, jam tenaga } \\
\text { kerja langsung }\end{array}$ \\
\hline Fokus pengukuran & $\begin{array}{l}\text { Biaya, kualitas, skala produk, } \\
\text { data keuangan, dan waktu }\end{array}$ & $\begin{array}{l}\text { Kinerja keuangan jangka } \\
\text { pendek }\end{array}$ \\
\hline Klasifikasi biaya & $\begin{array}{l}\text { Biaya variabel jangka pendek, } \\
\text { biaya variabel jangka panjang, } \\
\text { dan biaya tetap }\end{array}$ & Biaya variabel dan biaya tetap \\
\hline
\end{tabular}

Sedangkan menurut Carmelita et al. (2017) perbedaan yang paling mendasar pada kedua metode ini yaitu terletak pada proses identifikasi setiap aktivitas atau transaksi sebelum dibebankan kepada suatu produk. Dasar perbedaan sistem 
akuntansi biaya tradisional dengan Activity Based Costing System terletak pada biaya overhead dan dasar alokasinya. Sistem akuntansi biaya tradisional menggunakan pengukuran berdasarkan unit sebagai dasar pembebanan, sedangkan Activity Based Costing System menelusuri biaya ke setiap aktivitas produk atau jasa berdasarkan kebutuhan tingkat konsumsinya.

\section{Kelebihan Dan Kelemahan Activity Based Costing System}

Kelebihan dari Activity Based Costing system adalah memberikan kemudahan dalam menentukan biaya yang tidak realistis dan mengendalikan biaya overhead pada akuntansi biaya tradisional. Pihak manajemen juga dimudahkan dalam pengambilan keputusan yang dapat meningkatkan nilai jual dan profitabilitas perusahaan. Sedangkan kelemahan dari Activity Based Costing system adalah biaya yang terjadi tidak dapat mencakup seluruh biaya seperti dalam hal pemasaran, membutuhkan biaya yang sangat kompleks sehingga mempengaruhi biaya administrasi yang akan menjadi mahal (Carmelita et al., 2017).

Menurut Abdul (2005) dalam Rahmadani dan Wawo (2016) terdapat beberapa manfaat dari Activity Based Costing system, yaitu:

1. Mendorong perusahaan-perusahaan untuk membuat perencanaan secara spesifik atas aktivitas-aktivitas dan sumber daya untuk mendukung tujuan strategis.

2. Memperbaiki sistem pelaporan dan memperluas ruang lingkup informasi tidak hanya berdasar unit-unit organisasi tertentu. Sistem pelaporan yang dimaksud lebih luas di sini meliputi interdependensi antara satu unit dengan unit organisasi yang lain.

3. Dengan adanya interdependensi akan dapat mengenal aktivitas-aktivitas yang perlu dieliminasi dan yang perlu dipertahankan.

4. Penggunaan aktivitas-aktivitas sebagai pengidentifikasi yang alamiah akan lebih memudahkan pemahaman bagi semua pihak yang terlibat dalam perusahaan.

5. Lebih berfokus pada pengukuran aktivitas yang non finansial

6. Memberikan kelayakan dan kemampuan untuk ditelusuri atas pembebanan biaya overhead pabrik terhadap biaya produksi dengan menggunakan pemandu biaya sebagai basis alokasi.

7. Memberi dampak pada perencanaan strategis, pengukuran kinerja, dan fungsi manajemen yang lain

Sedangkan menurut Siregar et al. (2013) manfaat dari Activity Based Costing system, antara lain:

1. Pengukuran profitabilitas yang lebih baik. Biaya setiap aktivitas dapat dibebankan dengan lebih akurat dan terperinci ke dalam produk atau jasa, sehingga hasil penawaran produk atau jasa mudah ditelusuri. Selain itu, profitabilitas juga menjadi lebih mudah diketahui kaitannya dengan suatu produk atau jasa.

2. Pembuatan keputusan yang lebih baik. Informasi penggunaan aktivitas yang lebih detail menjadikan manajemen dapat menganalisis dampak atau hasil 
dari suatu aktivitas sehingga dapat memberi dasar pembuatan keputusan yang akurat.

3. Perbaikan proses (process improvement). Activity Based Costing system memberikan informasi detail mengenai penggunaan aktivitas. Hal ini memudahkan manajemen menelusuri dan menganalisis efektivitas dan efisiensi biaya aktivitas. Kemudian aktivitas-aktivitas yang dianggap tidak memberi nilai tambah dapat dihilangkan, sementara aktivitas-aktivitas yang belum optimal dapat dioptimalkan.

4. Estimasi biaya. Ketersediaan informasi penggunaan aktivitas dan biaya di masa lalu yang terperinci dapat memberikan dasar yang akurat dalam penentuan estimasi biaya di masa depan.

5. Penentuan biaya kapasitas tak terpakai. Estimasi biaya yang akurat atas suatu aset atau sumber daya pada suatu kapasitas yang dianggarkan dapat menjadi dasar penentu nilai biaya dari kapasitas yang tidak digunakan akibat inefisiensi produksi atau pelayanan.

Selain itu, terdapat beberapa keterbatasan dari Activity Based Costing system, sebagai berikut:

1. Alokasi. Tidak semua biaya memiliki aktivitas atau pemicu konsumsi sumber daya yang sesuai. Beberapa biaya perlu dialokasikan ke departemen dan produk berdasarkan pengukuran volume arbiter karena mencari aktivitas yang memicu biaya tidak praktis. Contohnya biaya sistem informasi untuk pemeliharaan fasilitas pabrik, gaji manajer pabrik, asuransi pabrik, dan pajak properti pabrik.

2. Pengabaian biaya (omission of cost). Biaya produk atau jasa yang diidentifikasi oleh Activity Based Costing system cenderung tidak memasukkan semua biaya yang terkait dengan produk atau jasa, seperti biaya untuk aktivitas pemasaran, riset periklanan, pengembangan, dan rekayasa produk. Meskipun beberapa biaya dapat ditelusuri langsung ke produk atau jasa individual. Biaya produk tidak memasukkan biaya-biaya ini karena prinsip-prinsip akuntansi untuk pelaporan keuangan mengharuskan biaya tersebut diperlakukan sebagai biaya periode.

3. Biaya dan waktu. Salah satu kendala terbesar dalam penerapan Activity Based Costing system adalah besarnya biaya aplikasi dan lamanya proses implementasi Activity Based Costing system. Hal ini karena Activity Based Costing system bukan masalah menghitung biaya produk semata, tetapi lebih pada cara manajemen mengidentifikasi aktivitas-aktivitas dalam produksi, sumber daya yang dikonsumsinya, hal-hal yang memicu biaya aktivitas tersebut, dan besarnya biaya yang terjadi.

\section{Keunggulan Bersaing}

Keunggulan bersaing adalah kemampuan perusahaan untuk dapat mempertahankan posisi dari para pesaingnya (Li et al., 2006). Dengan mempertahankan posisi memungkinkan perusahaan untuk mendapatkan profit yang lebih tinggi dari kompetitor (Chen et al., 2006). Sedangkan menurut Porter (1985) dalam Marlina et al. (2018) keunggulan bersaing adalah kemampuan perusahaan untuk menciptakan produk yang lebih murah atau bersifat 
unik/berbeda dari pesaing dengan beberapa aspek yang dikenal oleh pelanggan. Keunggulan bersaing harus mampu menjelaskan dan menanamkan nilai bisnis kepada konsumen sehingga mampu membentuk persepsi tersendiri di mata konsumen. Artinya pebisnis harus meyakinkan konsumen untuk bersedia mengeluarkan waktu dan uangnya untuk mendapatkan manfaat dan nilai sepadan. Cravens (2002) berpendapat bahwa keunggulan bersaing adalah jantung kinerja perusahaan dalam pasar bersaing. Keunggulan bersaing pada dasarnya tumbuh dari nilai atau manfaat yang dapat diciptakan perusahaan bagi para pembelinya.

Bila perusahaan kemudian mampu menciptakan keunggulan melalui salah satu dari ketiga strategi generik tersebut, maka akan didapatkan keunggulan bersaing. Hunger dan Wheelen (2003) menyatakan bahwa keunggulan bersaing merupakan kumpulan strategi untuk menentukan keunggulan suatu perusahaan dari persaingan di antara perusahaan lain. Strategi bersaing meliputi biaya rendah (low cost) dan diferensiasi, sedangkan kombinasi kedua strategi tersebut disebut fokus. Muhammad (2004) menyatakan bahwa perusahaan berusaha memproduksi dan memasarkan barang dan jasa dengan strategi bersaing yang menjadikan keunggulan dari perusahaan lain. Bagi investor, keunggulan bersaing bisa menjadi alat ukur untuk menilai kelayakan dan kinerja bisnis. Apakah perusahaan dapat memberikan return of investment yang baik bagi para investor atau tidak. Dalam menyusun strategi keunggulan bersaing, ada dua faktor yang perlu diperhatikan. Pertama, sumber daya yaitu kemampuan perusahaan dalam memproduksi barang, dan kedua adalah kinerja, yaitu kemampuan perusahaan mengolah produk jadi, dan mampu menyampaikannya kepada konsumen.

\section{Strategi Keunggulan Bersaing}

Menurut Porter (1985) terdapat 3 jenis strategi di dalam mewujudkan keunggulan bersaing, yaitu:

1. Strategi Cost Leadership (Strategi Biaya Rendah)

Menurut strategi ini, perusahaan meningkatkan value produk namun menurunkan harga. Value yang dimaksud adalah nilai persepsi konsumen terhadap produk. Strategi ini ditujukan untuk konsumen yang peka terhadap harga murah dan tidak membutuhkan merek produk untuk mengambil keputusan. Untuk menerapkan strategi ini, perusahaan harus memiliki teknologi yang baik, kemampuan untuk optimasi kapasitas, kemampuan untuk menekan harga, dan kemudahan akses bahan baku.

2. Strategi Diferensiasi

Strategi diferensiasi dilakukan pada pasar red ocean atau pasar yang memiliki banyak persaingan. Pada strategi ini, perbedaan yang dimiliki oleh produk harus dimiliki, agar mampu mendapatkan konsumen sendiri. Contohnya adalah strategi diferensiasi yang diterapkan pada produk smartphone di mana Apple memiliki fitur keamanan dan eksklusifitas, sedangkan produk Android lebih pada kustomisasi dan terbuka.

3. Strategi Fokus

Strategi fokus merupakan gabungan dari strategi diferensiasi dan biaya rendah (low cost). Menurut strategi ini perusahaan harus memilih pasar yang lebih sempit, yang biasa disebut dengan ceruk pasar (niche market). Ada 
syarat yang harus diperhatikan dalam melaksanakan strategi fokus. Pertama, di pasar tersebut memiliki potensi yang cukup baik dan berkelanjutan, kedua tidak ada pesaing di dalamnya atau memiliki pesaing yang sangat sedikit. Biasanya strategi ini berfokus melayani pasar tertentu, lokasi tertentu, dan juga kelompok masyarakat tertentu. Contoh, produsen mobil mewah yang sulit ditemukan di Indonesia.

\section{Alat Ukur Keunggulan Bersaing}

Keunggulan bersaing dalam bisnis juga perlu diukur. Apakah layak atau tidak dikatakan bisnis tersebut telah unggul untuk bersaing. Ada dua alat pengukuran yaitu balanced scorecard dan juga triple bottom line.

\section{Balanced Scorecard}

Menurut Hafidh (2020) Balanced Scorecard adalah alat pengukuran yang wajib dimiliki oleh perusahaan baik dalam kelayakan bisnis dan juga keunggulan berkompetisi. Menurut Balanced Scorecard ada empat perspektif yang harus dinilai pada bisnis, yaitu:

1. Perspektif keuangan

Adalah seberapa mampu perusahaan mengelola keuangan bisnisnya. Mulai dari perencanaan, operasional, hingga pembelian bahan-bahan produksi.

2. Perspektif konsumen

Adalah seberapa loyal konsumen anda, bagaimana kepuasan konsumen anda, nilai apa yang dipandang konsumen terhadap produk anda, dan juga seberapa banyak pelanggan yang anda dapatkan.

3. Perspektif internal

Adalah mengukur bagaimana kualitas proses kegiatan internal bisnis secara keseluruhan mulai dari perencanaan, operasional, dan evaluasi.

4. Perspektif Sumber Daya Manusia Perusahaan (learning and growth)

Adalah indikator bagaimana karyawan dapat berkontribusi pada perusahaan dan kompetensi yang dimiliki karyawan.

\section{Triple Bottom Line (TBL)}

Triple Bottom Line pertama kali diperkenalkan oleh Elkington pada tahun 1994, merupakan tiga pilar dalam pengukuran kinerja, yaitu dari sisi ekonomi atau keuangan, sosial, dan lingkungan. Sebagai pengukur kinerja, konsep Triple Bottom Line seringkali dibagi ke dalam dua bagian besar, yaitu keuangan dan sosial. Triple Bottom Line kini terus diperhatikan oleh organisasi untuk melaporkan tanggapan mereka terkait isu keberlangsungan dari sisi lingkungan hidup, sosial, dan kinerja ekonomi. Tiga pilar ini saling mendukung untuk tercapainya keberlangsungan (sustainability). Ketiga pilar ini bersifat tidak mutually exclusive dan dapat menjadi mutually reinforcing, sehingga seringkali disebut sebagai Triple Bottom Line Sustainability (Felisia dan Limijaya, 2014). Untuk mencapai sustainability, perusahaan harus mencapai elemen-elemen dari sustainability dalam melaksanakan praktik Triple Bottom Line, yaitu (Smith and Sharicz, 2011): 
1. Tata kelola (governance) yaitu perusahaan harus berkomitmen terhadap isu Triple Bottom Line dan menjadikannya bagian dari tata kelola perusahaan.

2. Kepemimpinan (leadership) yaitu sejumlah kualitas yang perlu dimiliki oleh seorang pemimpin agar aspek sosial dan lingkungan menjadi bagian integral dari kegiatan organisasi.

3. Rencana bisnis (business plan). Isu sustainability harus menjadi bagian dari rencana strategis bisnis dan kegiatan sehari-hari, dengan kata lain isu tersebut harus diperhatikan secara komprehensif.

4. Pengukuran dan pelaporan (measure and report) yaitu pengukuran serta pelaporan terhadap aktivitas-aktivitas perusahaan terkait sustainability.

5. Pembelajaran organisasi (organisation learning) yaitu organisasi perlu terusmenerus belajar dan beradaptasi agar dapat memperlengkapi diri dalam menghadapi tantangan terkait Triple Bottom Line di masa mendatang.

6. Budaya (culture). Budaya organisasi merupakan hal yang penting dalam pelaksanaan praktik Triple Bottom Line.

7. Sistem informasi (information systems), di mana sistem informasi dapat dimanfaatkan untuk mencapai eco-efficiency, eco-equity, serta ecoeffectiveness dalam suatu organisasi

\section{Kinerja Perusahaan}

Kinerja perusahaan adalah kemampuan organisasi dalam memanfaatkan sumber daya secara efektif dan efisien untuk mencapai tujuannya dan juga memberikan nilai kepada pelanggan dan para pemangku kepentingan (Marlina et al., 2018). Menurut Daft (2000) kinerja perusahaan adalah kemampuan perusahaan untuk mencapai tujuannya dengan memanfaatkan sumber daya secara efektif dan efisien. Antony and Bhattacharyya (2010) mengatakan bahwa kinerja perusahaan digambarkan sebagai sejauh mana perusahaan mampu dikelola dan diatur sehingga dapat memberikan nilai kepada pelanggan dan pemangku kepentingan. Sedangkan Rendy dan Devie (2013) berpendapat bahwa kinerja perusahaan adalah kemampuan organisasi dalam memanfaatkan sumber daya secara efektif dan efisien untuk mencapai tujuannya dan juga memberikan nilai kepada pelanggan dan para pemangku kepentingan. Kinerja perusahaan merupakan perbandingan dari hasil aktual atau output dari sebuah organisasi dengan hasil yang diinginkan atau target (Jahansahi et al., 2011). Dari beberapa pendapat di atas, dapat disimpulkan bahwa kinerja perusahaan merupakan pencapaian tujuan perusahaan dengan menggunakan sumber daya secara efektif dan efisien. Menurut Jahansahi et al. (2011) kinerja perusahaan terbagi menjadi 3 dimensi, yaitu:

1. Kinerja keuangan (tingkat pengembalian atas penjualan, profitabilitas, peningkatan penjualan, perbaikan produktivitas kinerja, perbaikan biaya produksi).

2. Kinerja operasional (pangsa pasar, pengenalan produk baru, kualitas barang/jasa, efektivitas pemasaran, kepuasan pelanggan).

3. Kinerja berbasis pasar (tingkat pengembalian pada pemegang saham, market value added, and keuntungan tahunan). 


\section{Implikasi Activity Based Costing Terhadap Keunggulan Bersaing Dan Peningkatan Kinerja Perusahaan \\ Kajian Singkat Beberapa Riset Terdahulu}

Beberapa hasil riset di bawah ini menjadi acuan di dalam membahas persoalan-persoalan menyangkut implementasi Activity Based Costing system. Hasil-hasil riset terdahulu menunjukkan bahwa pemanfaatan metode Activity Based Costing system di dalam menentukan biaya produksi dapat berpengaruh terhadap keunggulan bersaing perusahaan sehingga kinerja perusahaan meningkat. Riset-riset tersebut adalah sebagai berikut:

1. Bogdanoiu (2009) dalam penelitiannya mengatakan bahwa Activity Based Costing adalah metode yang menghasilkan biaya dari tiap aktivitas untuk cost object seperti produk atau jasa dengan cara menghitung biaya dan performa dari aktivitas dan sumber daya, sehingga Activity Based Costing system memberikan informasi biaya yang lebih akurat dibandingkan dengan sistem tradisional dan dapat digunakan oleh manajer untuk pengambilan keputusan sebagai dasar untuk mendapatkan keunggulan bersaing.

2. Penelitian Marlina (2017) menunjukkan Activity Based Costing berpengaruh terhadap keunggulan bersaing.

3. Penelitian Sumarsid (2011) mengatakan bahwa Activity Based Costing dapat mencegah perusahaan menghitung harga pokok produk yang overcosting (biaya yang dibebankan lebih dari yang seharusnya) atau undercosting (biaya yang dibebankan kurang dari yang seharusnya), sehingga metode Activity Based Costing dapat menurunkan harga jual produk dan dapat memperoleh keunggulan bersaing.

4. Ditunjang dengan penelitian Rendy dan Devie (2013), serta Marlina et al. (2018) yang juga menyebutkan bahwa terdapat pengaruh yang significant penerapan Activity Based Costing system terhadap keunggulan bersaing.

5. Penelitian yang dilakukan oleh Agha et al. (2012) meneliti hubungan keunggulan bersaing dengan kinerja perusahaan di perusahaan cat di United Arab Emirates. Hasil yang diperoleh adalah keunggulan bersaing berdampak positif terhadap kinerja perusahaan. Agha et al. (2012) mengukur keunggulan bersaing berdasarkan 2 dimensi yaitu flexibility dan responsiveness, sedangkan kinerja perusahaan diukur berdasarkan 2 dimensi yaitu pertumbuhan (growth) dan profitabilitas.

6. Penelitian lain juga diungkapkan oleh Li et al. (2006) yang mengatakan bahwa keunggulan bersaing mempunyai pengaruh positif dengan kinerja perusahaan. Sebagai contoh, jika perusahaan menerapkan strategi harga yang lebih murah dibandingkan pesaing, maka perusahaan tersebut mempunyai kemampuan keuangan yang baik. Li et al. (2006) mengukur keunggulan bersaing berdasarkan harga, kualitas, delivery dependability, inovasi produk dan time to market. Sedangkan kinerja organisasi diukur berdasarkan kinerja berbasis pasar (Market performance) dan kinerja keuangan (financial performance).

7. Penelitian yang dilakukan oleh Chen et al. (2006) mengatakan bahwa semakin tinggi keunggulan bersaing di suatu organisasi, maka semakin tinggi pula tingkat kinerja organisasi yang dimiliki oleh organisasi tersebut. 
8. Kinerja organisasi digambarkan sebagai sejauh mana organisasi mampu dikelola dan diatur sehingga dapat memberikan nilai kepada pelanggan dan pemangku kepentingan (Antony and Bhattacharyya, 2010).

\section{Implementasi Efektif Activity Based Costing terhadap Keunggulan Bersaing dan Peningkatan Kinerja}

Dari paparan dan telaah hasil riset diperoleh gambaran bahwa Activity Based Costing merupakan sistem yang sangat komprehensif dan kompleks. Pengadopsian sistem ini juga tidak selamanya akan memberikan manfaat bagi perusahaan, sesuai dengan keterbatasan Activity Based Costing system yang telah diuraikan di atas. Menelaah riset dari Gordon and Silvester (1999) diperlukan pertimbangan dan studi kelayakan yang matang sebelum memutuskan untuk menggunakan sistem ini. Bila diabaikan, maka pengadopsian sistem justru menjadi kontra produktif, dikarenakan sistem baru tidak akan memberikan kontribusi yang berarti bagi perusahaan. Hal lain yang perlu dipertimbangkan adalah bahwa sistem (manajemen) biaya yang baru ini membutuhkan biaya dan membutuhkan waktu yang tidak sedikit (Swenson, 1995). Kaplan and Cooper dalam Narayanan and Sarkar (1999) menyatakan bahwa yang seharusnya mengadopsi Activity Based Costing system adalah perusahaan-perusahaan yang mempunyai karakteristik sebagai berikut:

1. Berfokus terhadap area yang mengonsumsi biaya besar, khususnya terkait dengan penggunaan sumber daya pendukung dan tidak langsung.

2. Bervariasi dalam produk, pelanggan, dan proses.

Dari karakteristik potensial tersebut, tampak bahwa perusahaan yang bersifat ekspansif dan menghasilkan produk secara massal seharusnya mengadopsi sistem ini. Sistem Activity Based Costing berkarakteristik dinamis, mengingat semakin bervariasinya produk, pelanggan, maupun proses berarti semakin bervariasi pula aktivitas yang dikonsumsi (Adi, 2005). Namun demikian, dari hasil penelitian Activity Based Costing system tetap memberikan perspektif positif terhadap perbaikan kinerja perusahaan. Peranan Activity Based Costing system di dalam menciptakan keunggulan bersaing dan peningkatan kinerja adalah sebagai berikut:

1. Memberikan indikasi bahwa sistem ini mempunyai kemampuan untuk meningkatkan profitabilitas dari perusahaan. Sistem ini tidak hanya mampu dalam memperhitungkan biaya produk secara akurat, tetapi juga mampu di dalam mengidentifikasi produk, harga, maupun pelanggan yang tidak menguntungkan. Strategi perusahaan untuk segera mengeliminasi unsur yang tidak menguntungkan merupakan langkah awal peningkatan profitabilitas. Dengan menggunakan asumsi bahwa unit terjual dengan sama dengan tahun sebelumnya, maka perusahaan sebenarnya telah berhasil meningkatkan keuntungan (Narayanan and Sarkar, 1999).

2. Perusahaan dapat mengambil keputusan tepat terhadap jenis dan harga produk. Perusahaan mengambil keputusan untuk rnenghentikan produksi produk-produk yang tidak menguntungkan dan terkait dengan harga-harga produk yang tidak menguntungkan. Berkaitan dengan pelanggan, tampaknya perusahaan tidak dengan gegabah memutuskan hubungan dengan pelanggan 
yang menurut analisis tidak menguntungkan. Strategi yang tepat dilakukan terhadap pelanggan adalah bagaimana tetap mempertahankan pelanggan dan menjadikan mereka pelanggan yang menguntungkan.

3. Informasi di dalam Activity Based Costing system dapat digunakan untuk berbagai kepentingan lain, antara lain untuk pengambilan keputusan strategis operasional menyangkut perbaikan proses dan desain produk baru (Swenson 1995). Partridge and Lew (1998) mengidentifikasi ada 25 kebijakan strategis yang dapat dilakukan setelah memanfaatkan informasi Activity Based Costing. Gambaran tersebut menunjukkan bahwa, dalam praktiknya, implementasi Activity Based Costing membutuhkan partisipasi dan kerjasama aktif antar berbagai bagian departemen yang ada dalam perusahaan.

4. Dalam menciptakan keunggulan bersaing, perusahaan harus menyediakan layanan dan produk yang berkualitas tinggi serta harga yang lebih murah dibandingkan pelanggan (Baykasoglu and Kaplanoglu, 2008), karena pelanggan lebih tertarik memilih barang dengan harga yang terjangkau, tetapi dengan kualitas yang sama atau bahkan lebih baik dari pesaing. Bergman (1995) mengatakan harga adalah faktor yang menentukan kepuasan pelanggan. Dengan tuntutan seperti itu, para manajer perusahaan memerlukan informasi mengenai biaya produksi yang digunakan dalam rangka memproduksi produk yang akan dilempar ke pasaran. Dengan mempelajari biaya produksi maka harapan manajer adalah menekan biaya agar dapat melakukan penghematan dan pengendalian biaya produksi dalam rangka untuk dapat menciptakan harga jual yang kompetitif (Siswanto, 2004). Harga jual tidak boleh terlalu rendah agar dapat menutup semua biaya yang dikeluarkan perusahaan dan memberikan keuntungan yang diinginkan, juga tidak boleh terlalu tinggi agar perusahaan dapat bersaing dengan para pesaingnya. Suatu organisasi dapat menetapkan harga jual dengan tepat jika perusahaan dapat menghitung biaya produksi dengan tepat juga. Oleh karena itu, perhitungan biaya produksi yang dikeluarkan perusahaan untuk menghasilkan suatu produk pun haruslah akurat, sehingga perusahaan dapat menentukan harga jual yang kompetitif di pasar global ini.

5. Ward dan Patel (1990) menunjukkan bahwa Activity Based Costing merupakan sistem yang kompleks. Pemanfaatan Activity Based Costing selain mendorong pengambilan keputusan investasi juga memungkinkan perusahaan rnenetapkan standar operasional yang tepat, baik dari segi permanfaatan waktu, sumber daya manusia, maupun sumber daya yang lainnya. Pemanfaatan Activity Based Costing relatif memberikan jaminan adanya alokasi sumber daya secara efisien dan efektif, khususnya dalam rangka untuk menghasilkan keuntungan. Perbaikan kinerja seiring dengan naiknya keuntungan merupakan sinyal positif untuk menaikkan nilai saham perusahaan. Kemungkinan mendapatkan dividen saham lebih terbuka, sedangkan bagi yang berniat menjual saham keuntungan yang diperoleh (gain) juga akan lebih besar seiring dengan naiknya nilai jual saham yang dimiliki. Hubungan Activity Based Costing dengan nilai pasar nampak seperti bagan pada Gambar 2. 


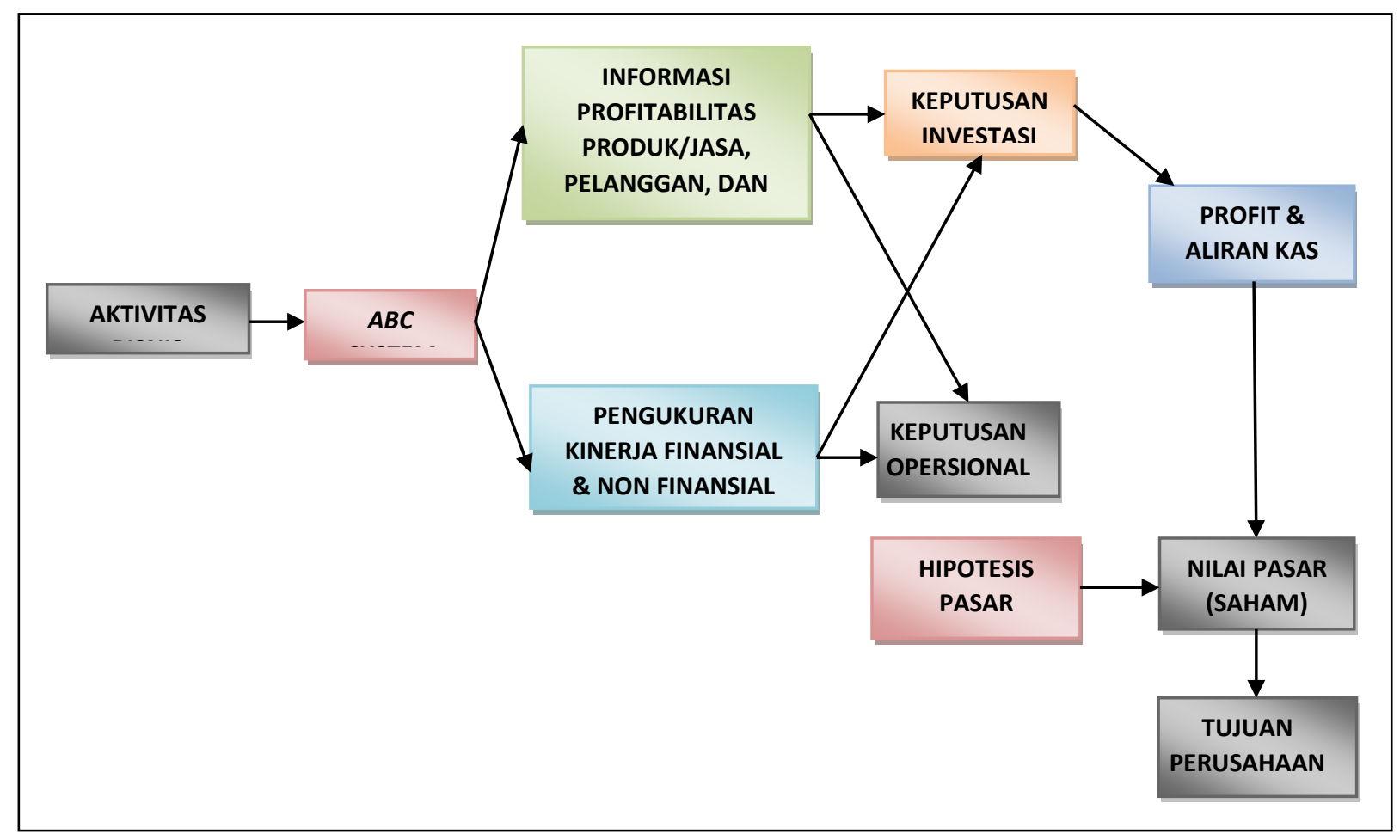

Gambar 2

Hubungan $A B C$ system dan Nilai Pasar (Ward and Patel, 1990)

\section{Dukungan Teknologi (Informasi)}

Sebagaimana disebutkan, sistem ini harus dapat memberikan respon yang cepat dalam mengatasi dinamika yang terjadi, khususnya pasar. Perusahaan harus mengambil keputusan secara cepat untuk menarik produk, mengevaluasi, merevaluasi harga produk, memperbaiki fungsi dan bentuk, melakukan diversifikasi ataupun melakukan keputusan strategis lain. Dukungan teknologi (informasi) yang memadai akan mendorong perusahaan untuk segera mengambil keputusan yang relevan dan tepat waktu dalam merespon dinamika yang tejadi dalam dunia bisnis, terkhusus dalam menghadapi persaingan (Nair, 2002). Akses terhadap teknologi merupakan kunci sukses dalam memenangkan persaingan.

\section{Kerja Tim}

Implementasi Activity Based Costing system tidak hanya melibatkan bagian akuntansi saja, tetapi juga bagian lain (Partridge and Lew, 1998; Friedman and Lyne, 1995). Dengan kata lain implementasi Activity Based Costing system sebenarnya berpotensi untuk menimbulkan konflik horisontal, mengingat adanya kemungkinan setiap karyawan yang terlibat lebih mengutamakan kepentingan dan tujuan bagian masing-masing. Kerja tim merupakan variabel yang penting dalam pengambilan keputusan untuk mengimplentasikan Activity Based Costing system (Morakul and Wu, 2001).

Dalam konteks ini dapat dilihat bahwa jenis dan fungsi dalam struktur organisasi memegang peranan penting dalam pengimplementasian sistem. Persoalan tugas dan delegasi wewenang menjadi hal yang penting dalam 
pembentukan dan peningkatan kerjasama tim guna menunjang efektifitas sistem. Faktor penting lain yang dapat menumbuhkan semangat kerja kolektif tersebut adalah bagaimana budaya organisasi yang dikembangkan dan bagaimana proses komunikasi interpersonal terjalin dalam perusahaan.

\section{Mekanisme Kontrol dan Pengukuran Kinerja yang Tepat}

Sebuah sistem akan berjalan dengan baik, apabila didukung dengan mekanisme kontrol dan pengukuran kinerja yang memadai. Manajemen harus mempunyai seperangkat pengukuran yang jelas untuk mengevaluasi dan menilai efektifitas pelaksanaan sistem (mengukur aktivitas-aktivitas) dan menilai kinerja (profitabilitas). Pengendalian perusahaan tidak hanya terfokus pada output, tetapi juga pada proses. Baik proses maupun output (yang tercermin dalam kinerja) tersebut akan dievaluasi dengan mengacu pada rencana strategis yang disepakati. Sebagai sistem yang terintegrasi, Activity Based Costing system hendaknya tidak hanya memprioritaskan aspek finansial tetapi juga aspek non finansial (Dolinsky and Vollman, 1991). Untuk itu, diperlukan juga seperangkat pengukuran untuk menilai efektifitas maupun efisiensi aspek non finansial ini. Contoh aspek non finansial yaitu: loyalitas pelanggan, mutu produk, ketepatan waktu pemasaran produk, dedikasi karyawan, dan sebagainya). Diharapkan juga di dalam perusahaan tercipta mekanisme saling kontrol antar bagian. Hubungan antara rencana strategis dan pengukuran kinerja dijelaskan dalam Gambar 3.

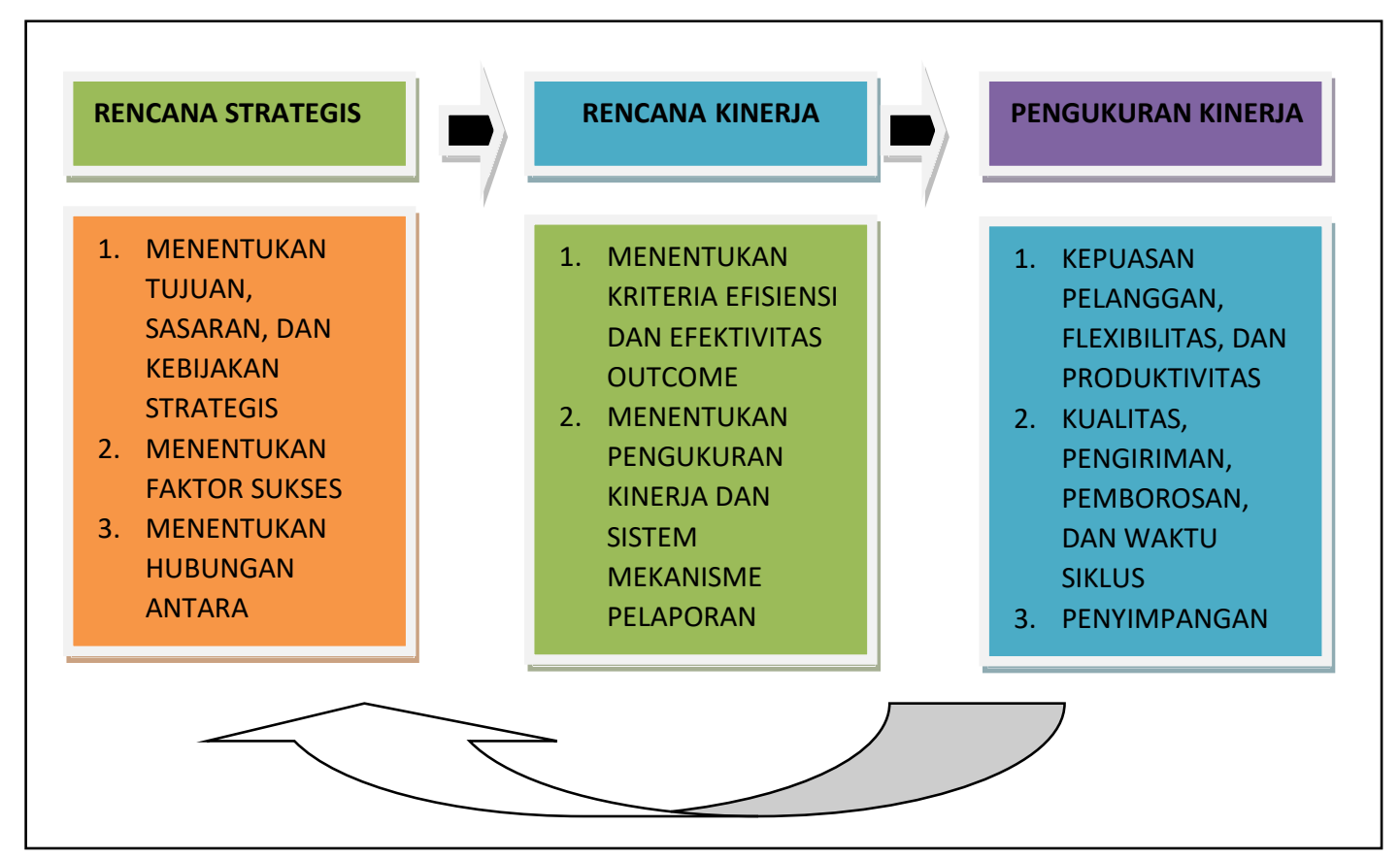

Gambar 3

Metodologi Pengukuran Kinerja dengan Menggunakan Metode Activity Based Costing System (Amos et al, 1997 dalam Adi, 2005) 


\section{SIMPULAN}

Sistem perhitungan biaya berbasis Activity Based Costing system merupakan jawaban dari model perhitungan biaya tradisional yang dianggap sudah tidak akurat dan tidak relevan dengan situasi dan kondisi yang ada. Activity Based Costing system tidak hanya mampu memperhitungkan biaya produk secara akurat, tetapi juga mampu mengidentifikasi produk, harga, maupun pelanggan yang tidak menguntungkan. Dengan Activity Based Costing system perusahaan akan mampu menentukan mana produk-produk yang menguntungkan dan yang tidak menguntungkan, sehingga dapat segera mengambil keputusan untuk menghentikan lini produk yang tidak menguntungkan. Informasi yang didapat dari Activity Based Costing system akan mampu dipakai untuk pengambilan keputusan strategis operasional terkait perbaikan proses dan desain produk baru.

Perusahaan yang mengimplementasikan Activity Based Costing system diyakini akan memiliki keunggulan bersaing, karena mampu untuk menyediakan informasi yang akurat mengenai biaya produksi. Berdasarkan pemahaman yang akurat dan detail mengenai biaya produksi dan sumber yang menimbulkan biaya, perusahaan akan mampu untuk menekan biaya produksi melalui analisis cost driver secara lebih detail. Dengan demikian akan mampu dihasilkan produk dengan biaya rendah, sehingga harga jual akan dapat ditekan seminimal mungkin agar memiliki keunggulan bersaing. Activity Based Costing system juga memungkinkan perusahaan untuk menetapkan standar operasional yang tepat dan akurat, sehingga memberikan jaminan adanya alokasi sumber daya secara efektif dan efisien.

Implementasi Activity Based Costing system tidak hanya berfokus pada aspek finansial, namun juga pada aspek non finansial lain yang merupakan indikator keberhasilan kinerja suatu perusahaan. Namun demikian, berdasarkan riset, implementasi Activity Based Costing system belum memberikan hasil yang optimal bagi perusahaan di dalam peningkatan kinerja. Hasil dari beberapa riset menyebutkan bahwa adanya perbedaan di dalam lingkungan organisasi yang menyebabkan implementasi Activity Based Costing system bisa berhasil atau tidak di dalam peningkatan kinerja perusahaan

\section{SARAN}

1. Perlu adanya penelitian lebih lanjut tentang faktor-faktor apa sajakah yang berpengaruh terhadap keberhasilan implementasi Activity Based Costing system untuk meningkatkan kinerja perusahaan, sehingga perusahaan yang berkeinginan untuk menggunakan sistem ini dapat berhasil di dalam penerapannya. Selain itu, objek penelitian harus difokuskan dengan berbagai perusahaan yang berbeda dengan berbagai ukuran.

2. Perlu dilakukan analisis komparatif lebih spesifik terhadap pengaruh implementasi suatu sistem dengan sistem yang lain terhadap kinerja, sehingga dapat diperoleh gambaran hal-hal strategis manakah yang paling efektif untuk diterapkan untuk menghasilkan kinerja yang optimal bagi perusahaan 


\section{DAFTAR KEPUSTAKAAN}

Adi, Priyo Hari, 2005, Implementasi Activity Based Costing Terhadap Kinerja Perusahaan (Telaah Literatur), Jumal Ekonomi dan Bisnis, Vol. XI, No. 2, hal. 101-118.

Agha, Sabah, Laith Alrubaiee, and Manar Jamhour, 2012, Effect of Core Competence on Competitive Advantage and Organizational Performance, International Journal of Business and Management, Vol. 7, No. 1, page 192204.

Akyol, Derya Eren, Gonca Tuncel, and G. Mirac Bayhan, 2005, A Comparative Analysis of Activity-Based Costing and Traditional Costing, World Academy of Science, Engineering and Technology 3, page 44-47.

Amos, Tracey, Cynthia Paolillo, and Denise Joseph, 1997, Enhancing CFO, GMRA \& GPRA Implementation with Activity Based Management, Government Accountants Journal, Arlington, page 28-34.

Antony, J. P. and Bhattacharyya, S., 2010, Measuring Organizational Performance and Organizational Excellence of SMEs-Part 2: An Empirical Study on SMEs in India, Measuring Business Excelence, Vol. 14, No. 3, page 42-52.

Baykasoglu, A. and V. Kaplanoglu, 2008, Application of Activity Based Costing to A Land Transportation Company: A Case Study, Int. J. Production Economics, 116, page 308-324.

Bergman, R. L., 1995, Integrating Marketing, Operations, and Purchasing to Create Value, Omega, Vol. 23, No. 2, page 159-172.

Blocher, Edward J., Kung H. Chen, Gary Cokins, and Thomas W. Lin, 2005, Manajemen Biaya: Penekanan Strategis, Edisi Ketiga, Salemba Empat, Jakarta.

2007,

Manajemen Biaya: Penekanan Strategis, Edisi Ketiga, Salemba Empat, Jakarta.

Bogdanoiu, C., 2009, Activity Based Cost from The Perspective Of Competitive Advantage, Journal of Applied Economic Sciences, Vol. 4, No. 7, page 5-11.

Carmelita, Carissa Vaudia, Moch. Dzulkirom, A. R., dan Zahroh Z. A., 2017, Analisis Activity Based Costing System Dalam Penentuan Harga Pokok Produksi Guna Menentukan Harga Jual Gula (Studi Kasus Pada PT. PG. Kebon Agung Unit PG. Kebon Agung Kecamatan Pakisaji Kabupaten Malang), Jurnal Administrasi Bisnis (JAB), Vol. 48, No. 1, hal. 1-10.

Chen, Y. C., D. J. Leu, and H. C. Chiou, 2006, The Impact of E-Supply Chain Capability on Competitive Advantage and Organizational Performance, 
International Journal of Electronic Business Management, Vol. 4, No. 5, page 419-427.

Cravens, David W., 2002, Pemasaran Strategis, Phelindo, Jakarta.

Daft, R. L., 2000, Organization Theory and Design, 7th Edition, South-Western College Publishing, Thomson Learning, USA.

Dicky, Yoanes dan Riki Martusa, 2011, Penerapan Activity Based Costing (ABC) System Dalam Perhitungan Profitabilitas Produk, Jurnal Akuntansi, Vol. 3, No. 1, hal. 69-89.

Dollinsky, L. R. and T. E. Vollman, 1991, Transaction-Based Overhead Consideration for Product Design, Journal of Cost Management, page 7-19.

Felisia dan Amelia Limijaya, 2014. Triple Bottom Line dan Sustainability, Majalah Ilmiah Fakultas Ekonomi Unpar, Vol. 18, No. 1.

Friedman, A. L. and S. R. Lyne, 1995, Activity Based Techniques: The Real Consequenses, Chatered of Institute Management Accountant, London.

Gunasekaran, A., 1999, A Framework for The Design and Audit of An ActivityBased Costing System, Managerial Auditing Journal, Vol. 14, No. 3, page 118126.

Gordon, L. A. and K. J. Silvester, 1999, Stock Market Reaction to Activity-Based Costing Adoption, Journal of Accounting and Public Policy, Vol. 18, page 229251.

Hafidh, 2020. https://www.jurnal.id/id/blog/mengenal-keunggulan-kompetitifpada-bisnis/\#Kenapa_Keunggulan_Kompetitif_itu_Penting.

Hakim, Tito I. M. Rahman, 2018, Activity-Based Costing dan Derivatifnya serta Signifikansinya pada Lingkungan yang Mutakhir, The International Journal of Applied Business, Vol. 2, No. 2, hal. 107-122.

Halim, Abdul dan Bambang Supomo, 2005, Akuntansi Manajemen, BPFE, Yogyakarta.

Hilton, R. W., M. W. Michael, and S. H. Frank, 2003, Cost Management: Strategies for Business Decisions, The McGraw Hill Companies Inc., New York.

Hunger, J. David dan Thomas L. Wheelen, 2003, Manajemen Strategis, Andi, Yogyakarta.

Indrasurya, Beny, Moch. Dzulkirom A. R., Muhammad Saifi, 2016. Activity Based Costing (ABC) System Dalam Menentukan Tarif Layanan Rawat Inap (Studi Kasus Pada RSUD Dr. Harjono S. Kabupaten Ponorogo), Jurnal Administrasi Bisnis (JAB), Vol. 37, No. 2. 
Jahanshahi, A. A., M. Rezaei, K. Nawaser, V. Ranjbar, and B. K. Pitamber, 2012, Analyzing The Effects of Electronic Commerce on Organizational Performance: Evidence from Small and Medium Enterprises, African Journal of Business Management, Vol. 6, No. 15, page 6486-6496.

Kaplan, Robert S. and David P. Norton, 1996, The Balanced Scorecard Translating Strategy into Action, Harvard Business School Press, Boston, Massachusetts.

Li, Suhong, Bhanu Ragu-Nathan, T. S. Ragu-Nathan, and S. Subba Rao, 2006, The Impact of Supply Chain Management Practices on Competitive Advantage and Organizational Performance, The International Journal of Management Science, Vol. 34, Issue 2, page 107-124.

Marlina, Evi, 2017, Analisis Pengaruh Activity-Based Costing Terhadap Keunggulan Bersaing, In Celschiteh Prociding 2, ECO. hal. 28-35.

Marlina, Evi, Siti Samsiah, Hendri Ali Ardi, 2018, Analisis Pengaruh Activity Based Costing Terhadap Keunggulan Bersaing dan Kinerja Perguruan Tinggi, Jurnal Akuntansi dan Ekonomika. Vol. 8, No. 1.

Miller, J., A. De Meyer, and J. Nakane, 1992, Benchmarking Global Manufacturing, IL: Business One Irwin, Homewood.

Morakul, Supitcha and Fredrick Wu, 2001, Cultural Influences on The Implementation in Thailand's Environment, Journal of Managerial Psychology, Bradford, page 142-154.

Muhammad, Suwarsono, 2004, Manajemen Strategik: Konsep dan Kasus, UPP AMP YKPN, Yogyakarta.

Mulyadi, 2003, Activity-Based Cost System: Sistem Informasi Biaya untuk Pengurangan Biaya, Edisi Keenam, UPP AMP YKPN, Yogyakarta.

Nair, Mohan, 2002, Sistem Informasi Berbasis Aktivitas, Salemba Empat, Jakarta.

Narayanan, V. G. and Ratna G. Sarkar, 1999, The Impact of Activity Based Costing or Managerial Decisions at Insteel Industries-A Field Study, Harvad Business School, Boston.

Noviyarsi, Ayu Bidiawati, dan Eni Kurniati, 2017, Implementasi Activity Based Costing Untuk Penentuan Harga Pokok Produksi Cake Buah Naga Mocha, Jurnal Integrasi Sistem Industri, Vol. 4, No. 2, hal. 99-106.

Partridge, Mike and Perren Lew, 1998, An Integrated Framework for Activity Based Decision Making, Management Decision, London, hal. 580-590.

Pawiyataningrum, Agustina Nurul, Nengah Sudjana dan Zahroh Z. A., 2014, Penerapan Activity Based Costing (ABC) System untuk Menentukan Harga 
Pokok Produksi (Studi Pada PT. Indonesia Pet Bottle Pandaan Pasuruan), Jurnal Administrasi Bisnis (JAB), Vol. 10, No. 1, hal. 1-9.

Porter, M. E., 1985, Competitive Advantage Creating and Sustaining Superior Performance, The Free Press, New York.

Rahmadani, Nurfatimah dan Andi Wawo, 2016, Penentuan Harga Pokok Produksi Pembangunan Rumah Dengan Menggunakan Metode Activity Based Costing (Studi Pada Perum Perumnas Regional VII Makassar), Jurnal Ilmiah Akuntansi Peradaban, Vol. II, No. 1, hal. 108-128.

Rahman, Hendra Yulia dan Wartoyo, 2018, Implementasi Produksi Dalam Menghadapi Revolusi Industri (Studi Pada Provider Di Indonesia), Jurnal Kajian Ekonomi dan Perbankan 2, hal. 85-106.

Rahmaji, Danang, 2013, Penerapan Activity-Based Costing System untuk Menentukan Harga Pokok Produksi PT. Celebes Mina Pratama, Jurnal EMBA, Vol. 1, No. 3, hal. 63-73.

Reimann, Benard C., 1990, The ABC of Accounting of Value Creation, ABUINFORM Research, hal. 33-34.

Rendy dan Devie, 2013, Analisis Pengaruh Activity Based Costing Terhadap Keunggulan Bersaing dan Kinerja Organisasi, Jurnal Akuntansi dan Bisnis Universitas Kristen Petra.

Satya, Venti Eka, 2018, Strategi Indonesia Menghadapi Industri 4.0, Kajian Singkat Terhadap Isu Aktual dan Strategis, Vol. X., No. 09/I/Puslit/Mei/2018, hal. 19-24.

Siregar, Baldric, Bambang Suripto, Dody Hapsoro, Eko Widodo Lo, dan Frasto Biyanto, 2013, Akuntansi Manajemen, Salemba Empat, Jakarta.

Siswanto, 2004, Activity Based Costing Sebagai Metode Alternatif Meraih Keunggulan Kompetitif, Jurnal Pendidikan Akuntansi Indonesia, 3 (1), hal. 7177.

Smith, P. A. C. and C. Sharicz, 2011, The Shift Needed for Sustainability, The Learning Organization, Vol. 18, No. 1, page 73-86.

Suharman, Hari Wisnu Murti, 2019, Kajian Industri 4.0 untuk Penerapannya di Indonesia, Jurnal Manajemen Industri dan Logistik, Vol. 3, No. 1, hal. 1-13.

Sumarsid, 2011, Pendekatan Metode Activity Based Costing pada Perencanaan Harga Pokok Produksi untuk Memperoleh Keunggulan Bersaing, Jurnal Ilmiah Ekonomi Manajemen dan Kewirausahaan Optimal, Vol. 5, No. 1, hal. 71-90.

Swenson, D., 1995, The Benefits of Activity Based Cost Management to The Manufacturing Industry, Journal of Management Accounting Research, page 167-180. 
Tsai, W. H., 1998, Quality Cost Measurement Under Activity-Based Costing, International Journal of Quality \& Reliability Management, Vol. 15, No. 7, page $719-752$.

Ward, T. and K. Patel, 1990, ABC--- A Framework for Improving Shareholder Value, Management Accounting, Vol. 68, No. 7, page 34-36.

Widjaja, Amin, 1992, Activity Based Costing Suatu Pengantar, Rineka Cipta, Jakarta.

Witjaksono, Armanto, 2013, Akuntansi Biaya, Edisi Revisi, Graha Ilmu, Yogyakarta.

Yudiastra, Putu Pande, 2017, Analisis Perbandingan Metode Activity Based Costing dan Traditional Costing untuk Penentuan Harga Pokok Produksi (Studi Kasus pada UKM Bali Sari), Konferensi Nasional Sistem \& Informatika. 